\title{
PERLAWANAN ALIRAN DI KAPUAS KECIL
}

\author{
Hari Wibowo ${ }^{1)}$, Kartini ${ }^{2)}$ \\ 1,2 Jurusan Teknik Sipil FT UNTAN, Jl. Prof H Hadari Nawawi, Pontianak, Kalbar \\ email: hariwibowo@civil.untan.ac.id ${ }^{1)}$,kartini@civil.untan.ac.id ${ }^{2)}$
}

DOI: http://dx.doi.org/10.29103/tj.v10i1.270

(Received: January 2020 / Revised: February 2020 / Accepted: March 2020)

\begin{abstract}
Abstrak
Kekasaran dasar saluran sangat berpengaruh pada karakteristik aliran. Kesalahan dalam menentukan besarnya nilai kekasaran dasar saluran, terutama material dasar non kohesif, dapat menimbulkan kesalahan dalam menghitung kecepatan dan debit aliran. Kekasaran dasar saluran dinyatakan dalam koefisien kekasaran. Koefisien kekasaran saluran yang sering digunakan dalam aliran seragam adalah nilai koefisien kekasaran Manning (n). Banyak penelitian yang dilakukan untuk mendapatkan nilai koefisien kekasaran Manning, diantaranya didasarkan $\mathrm{n}$ tabel. Nilai $\mathrm{n}$ tabel Manning hanya disarankan untuk saluran kondisi baik. Kondisi aliran saluran alami penerapan $\mathrm{n}$ tabel Manning sering memberikan hasil sangat kasar, karena keadaan aliran lebih banyak tergantung faktor. Salah satunya faktornya, adanya bentuk konfigurasi dasar atau dasar tidak rata, oleh karena itu, kajian mendalam mengenai perhitungan nilai koefisien kekasaran Manning dengan bentuk konfigurasi dasar menjadi sangat penting. Tujuan penelitian, untuk mendapatkan rumusan empiris nilai koefisien kekasaran Manning saluran alam. Modifikasi koefisien kekasaran Manning, yang berkaitan butiran dasar dan bentuk dasar. Metode yang akan dilaksanakan berupa pembuatan rumusan empiris hubungan bentuk konfigurasi dasar saluran terhadap koefisien kekasaran dasar material non kohesif. Aplikasi penerapan rumusan akan dilakukan pada studi kasus Sungai Kapuas di kota Pontianak.
\end{abstract}

Kata Kunci: Perlawanan Aliran, Kekasaran Dasar, Saluran Aluvial, Sungai Kapuas

\begin{abstract}
The channel roughness is very influential in flow characteristics. Errors in determining the value of channel roughness values, especially non-cohesive basic materials, can cause errors in calculating flow velocity and flow. The channel roughness is stated in the roughness coefficient. The channel roughness coefficient that is often used in uniform flow is the value of the Manning roughness coefficient (n). Many studies have been conducted to get the value of the Manning roughness coefficient, including based on $\mathrm{n}$ tables. The $\mathrm{n}$ Manning table value is only recommended for good condition channels. The natural channel flow conditions of the application of Manning's $n$ tables often give very rough results, because the flow conditions depend more on factors. One of the factors is the existence of basic or uneven basic configuration forms. Therefore, An in-depth study of calculating the value of the Manning roughness coefficient with the basic configuration form becomes very important. The purpose of this research is to get an empirical formula for the roughness coefficient of the Manning natural channel. Modification of the Manning roughness coefficient, which is related to basic granules and basic shapes. The method to be carried out is in the form of making empirical formulation of the relationship between the form of the basic configuration of the channel to the non-cohesive basic material roughness coefficient. The application of the formulation will be carried out in the Kapuas River case study in Pontianak.
\end{abstract}

Keywords; Flow Resistance, Basic Roughness, Alluvial Canal, Kapuas River 


\section{Latar Belakang}

Parameter perlawanan aliran sangat mempengaruhi kondisi aliran. Salah satu nilai perlawanan aliran adalah nilai kekasaran Manning. Beberapa literatur dan buku telah memberikan nilai-nilai acuan yang dapat digunakan untuk menetapkan nilai perlawanan aliran pada rumusan Manning.

Perlawanan aliran pada bidang dasar rata dalam kondisi turbulen, hanya terdiri dari komponen kekasaran butiran saja atau fungsi geseran kulit atau tarikan permukaan (Kodoatie, 2009; Simons and Şentürk, 1992). Spesifik stream power pada angkutan sedimen, menyebabkan dasar saluran menjadi tidak stabil (Knighton, 1999), dan terjadinya bentuk konfigurasi dasar (Engelund and Hansen, 1967; Yalin, 1992). Ketika pembentukan dasar terjadi, maka form drag harus ditambahkan pada perlawanan bentuk (Toyama et al., 2007; van Duin et al., 2013).

Perlawanan bentuk $\left(n^{\prime \prime}\right)$ akibat konfigurasi dasar memberikan kontribusi perlawaan dasar lebih dominan, dibandingkan perlawanan kekasaran butiran (Talebbeydokhti et al., 2006; Van der Mark, 2009). Oleh karena itu, perkiraan perlawanan bentuk menjadi penting, dalam kaitannya dengan memprediksi perlawanan dasar (Wibowo, 2015, 2017)

Penelitian perlawanan akibat butiran dan perlawanan bentuk pada nilai koefisien kekasaran Manning, diantaranya Bajorunas et al. (1952) dan Talebbeydokhti et al. (2006). Keduanya menggunakan perlawanan kekasaran butiran, didasarkan (Strickler, 1923).

Perlawanan bentuk $\left(n^{\prime \prime}\right)$ (Einstein, 1952) berdasarkan pada rumusan koefisien kekasaran Manning. Namun, belum mengkaitkan form drag dengan bentuk dasar. (Talebbeydokhti et al., 2006a) mengembangkan penelitian Bajorunas (1952) dengan bentuk dasar dunes. Mereka menggunakan perlawanan bentuk pada rumusan nilai koefisien kekasaran Manning (n), terhadap kekasaran butiran rumusan Strickler (1923). Penelitian yang dilakukan oleh Bajorunas (1952) dan Talebbeydokhti et al. (2006), belum diteliti secara mendetail dari sudut pandang analitis, yang melibatkan perlawanan bentuk akibat konfigurasi dasar dan spesifik stream power.

Chow (1959) menggunakan nilai pendekatan berdasarkan jenis material dan kekasaraan permukaan saluran. Penentuan koefisien kekasaran Manning selanjutnya disusun dalam $\mathrm{n}$ tabel (Chow, 1959). Penggunaan nilai koefisien kekasaran Manning didasarkan $\mathrm{n}$ tabel. hanya disarankan pada saluran aliran seragam dengan dasar rata. Kondisi aliran saluran alami, penerapan $\mathrm{n}$ tabel Manning memberikan hasil sangat kasar. Keadaan aliran lebih banyak tergantung faktor yang tidak diketahui dari saluran buatan.

Kajian mendalam mengenai nilai koefisien kekasaran Manning dan hubungannya dengan bentuk konfigurasi dasar dan spesifik stream power menjadi penting untuk dikembangkan, sehingga dapat digunakan dalam menentukan nilai koefisien kekasaran yang lebih objektif. Oleh karena itu, masih perlu dilakukan pengembangan lebih lanjut terhadap nilai koefisien kekasaran Manning dengan memperhitungkan perlawanan bentuk akibat konfigurasi dasar dan spesifik stream power. Penelitian akan dilakukan di Sungai Kapuas Kecil di Pontianak. 


\section{Metode Penelitian}

Penelitian sebelumnya berfungsi untuk analisa dan memperkaya pembahasan penelitian, serta membedakannya dengan penelitian yang sedang dilakukan.

\subsection{Rumusan Penelitian Terdahulu}

Dalam penelitian ini disertakan jurnal internasional penelitian sebelumnya yang berhubungan dengan konsep sistem tata air dan kebakaran hutan, antara lain:

A. Bajorunas (1952). meneliti mengenai koefisien kekasaran Manning pada perlawanan butiran dasar saluran yang berhubungan dengan kekasaran butiran $\left(n^{\prime}\right)$, dan perlawanan aliran yang berkaitan dengan keberadaan bentuk dasar dan perubahannya, yang dikenal dengan kekasaran bentuk ( $n$ "). Rumusan tersebut, sebagaimana yang ditunjukan pada Persamaan 1

$$
n=n^{\prime}+n^{\prime \prime}
$$

$$
n^{\prime}=\frac{1}{29,3} \cdot d_{50}^{1 / 6}
$$

$$
n^{\prime \prime}=\phi\left(\frac{R^{\prime} S f}{1.68 d_{35}}\right)
$$

di mana:

$\mathrm{n} \quad=$ angka kekasaran Manning

$n^{I}=$ perlawanan yang dikarenakan gesekan permukaan (skin friction) atau kekasaran butiran, yang dinyatakan dalam Persamaan 2.

$n^{\prime \prime}=$ perlawanan yang dikarenakan form drag, sebagaimana Gambar (1) dan Persamaan 3

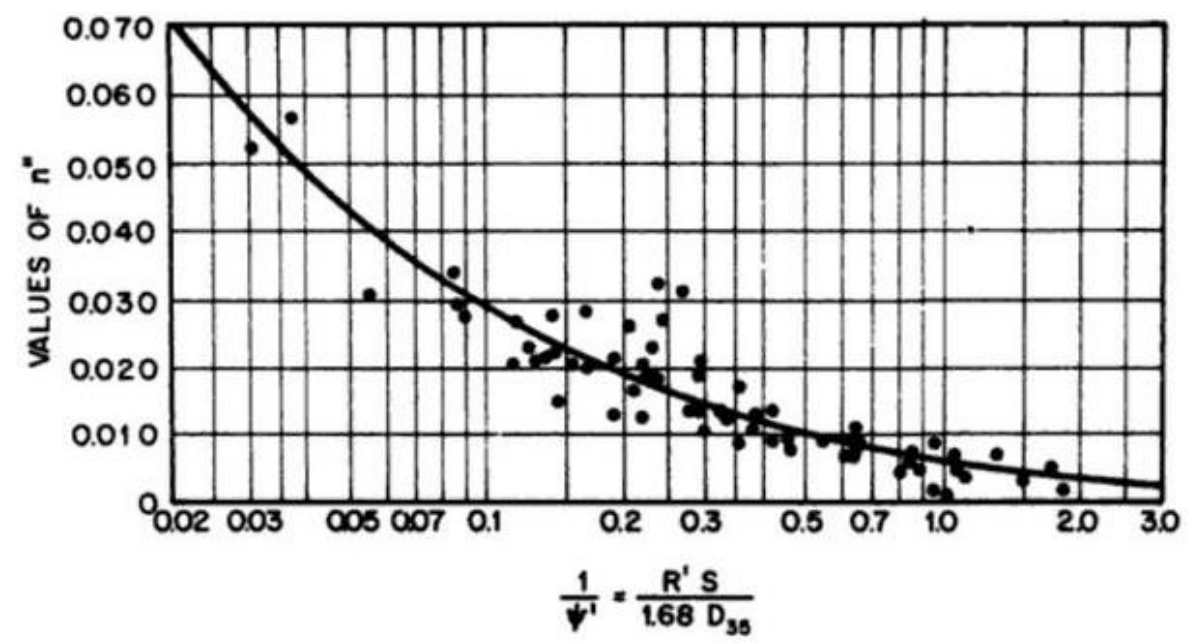

Gambar $1 n^{\prime \prime}$ sebagai Fungsi dari $\left(\frac{1}{\psi^{\prime}}\right)$ Bajorunas (1952)

Gambar 1 menunjukan bahwa, komponen perlawanan yang dikarenakan kekasaran butiran lebih dominan, dari kekasaran bentuk. Sehingga, hal ini 
tidak sama dengan penelitian (Kazemipour and Apelt, 1983), yang menyatakan bahwa hampir sembilan puluh persen dari total perlawanan aliran di dasar disebabkan oleh adanya kekasaran bentuk yang diakibatkan bentuk konfigurasi, maka pengaruh kekasaran bentuk ini tidak boleh diabaikan, oleh karenanya perlu dilakukan pengembangan lebih lanjut mengenai penelitian Bajorunas (1952).

B. (Talebbeydokhti et al., 2006a)). Mereka meneliti model pada bentuk dasar dunes dalam saluran dasar pasir yang berkaitan dengan koefisien kekasaran dasar, yang hampir menyerupai penelitian Bajorunas (1952), dengan pemisahan penjumlahan komponen aliran sebagaimana Persamaan 4:

$$
n^{\prime \prime}=0,02691\left(\frac{\Delta}{n}\right)+0,0026
$$

di mana

$$
\begin{aligned}
& n^{\prime \prime}=n-n^{\prime} \text { (kondisi dunes) } \\
& n^{\prime}=\frac{1}{21,1} \cdot d_{50}^{1 / 6}\left(d_{50}\right. \text { dalam meter). } \\
& n=\text { nilai koefisien kekasaran Manning (n table Mannning). }
\end{aligned}
$$

Pada penelitian Talebbeydokhti et al. (2006) terlihat untuk kekasaran bentuk $\left(n^{\prime \prime}\right)$ masih menggunakan $\mathrm{n}$ tabel.

C. Rumusan Perubahan Konfigurasi Dasar, Beberapa kajian yang telah dilaksanakan sehubungan dengan dimensi bentuk dasar pada kondisi aliran dan angkutan sedimen terutama pada dunes (Van Rijn, 1993).

Garde dan Issac (1993) : $\frac{\Delta d}{h}=F\left(F r^{\prime} \frac{h}{d}\right)=4,58(F r)^{0,397}\left(\frac{h}{d}\right)^{0,0546}$

Allen (1968)

$$
: \frac{\Delta d}{h}=0,086 h 0,{ }^{0,19} \text { dan } \frac{\lambda d}{h}=h^{0,60}
$$

Garde dan Issac (1993) : $\frac{\Delta d}{h}=F\left(F r^{\prime} \frac{h}{d}\right)=4,58(F r)^{0,397}\left(\frac{h}{d}\right)^{0,0546}$

Van Rijn (1984)

$$
: \frac{\Delta d}{h}=0,11\left(\frac{d_{50}}{h}\right)^{0,3}\left(1-e^{-0,5 T}\right)(25-T)
$$

di mana

$$
\begin{aligned}
& \Delta_{\mathrm{d}}=\text { tinggi dunes } \\
& \lambda_{\mathrm{d}}=\text { panjang dunes } \\
& \mathrm{Fr}=\text { Bilangan Froude. } \\
& \mathrm{d}_{50}=\text { diameter partikel median. } \\
& \mathrm{h} \quad=\text { kedalaman air dari permukaan air sampai elevasi dasar rerata }(\mathrm{m}) \\
& \mathrm{T} \quad=\text { menyatakan parameter tegangan geser dasar. } \\
& U_{*}=\text { kecepatan geser partikel } \\
& w \quad=\text { kecepatan jatuh. }
\end{aligned}
$$




\subsection{Tahapan Kegiatan Penelitian}

Tahapan kegiatan penelitian ini dimulai dari studi lapangan yang dilakukan secara terjadwal dan terstruktur dan berdasarkan studi lapangan maka diidentifikasi masalah-masalah yang terjadi serta dilakukan perumusan masalah. Kemudian ditetapkan tujuan penelitian.

Dengan ditetapkannya tujuan penelitian maka akan menjadi lebih jelas kebutuhan data dan dilakukan pengumpulan data yang terdiri dari data primer dan data sekunder.

Langkah selanjutnya dilakukan analisis data yang dilakukan dengan 2 metode yaitu dengan menggunakan model matematika dan dengan menggunakan rumusan empiris.

\section{Hasil dan Pembahasan}

\subsection{Pengambilan Sedimen di Dasar Sungai}

Pengambilan sedimen dasar sungai dilakukan di tiga titik, yaitu tepi-tengahtepi. Tiga titik pengambilan ini diharapkan dapat mewakili sedimen dasar pada daerah lokasi penelitian.

Pengambilan sampel dilakukan dengan menggunakan Grab sampling. Grab sampling adalah proses yang simpel dalam mengangkat sedimen permukaan dari dasar sungai. Dalam Grab Sampling alat-alat yang digunakan adalah grab sampler dan core sampler.

\subsection{Hasil Analisa Uji Sedimen Dasar Sungai Kapuas Kecil}

Hasil sedimen pada beberapa lokasi pengamatan pada Sungai Kapuas Kecil, dapat dilihat sebagaimana pada Gambar 2.



Gambar 2 Pengambilan Data Sampel Dasar pada Titik 1 Sungai Kapuas Kecil

Berdasarkan hasil analisa gradasi diperoleh bahwa material dasar sebagian besar merupakan jenis pasir. Dengan demikian maka akan terbentuk bentuk dasar sungai. 
Tabel 1 Hasil Uji Karekteristik Tanah

\begin{tabular}{|c|c|c|c|c|c|c|c|}
\hline \multirow{3}{*}{ No } & \multirow{3}{*}{ Location } & \multirow{3}{*}{ Gs } & \multirow{3}{*}{$\begin{array}{l}\gamma \mathbf{m} \\
\mathrm{t} / \mathrm{m} 3\end{array}$} & \multirow{3}{*}{$\begin{array}{c}\Phi \\
(\mathrm{o})\end{array}$} & \multicolumn{3}{|c|}{ MIT Classification } \\
\hline & & & & & \multicolumn{3}{|c|}{ diameter $(\mathbf{m m})$} \\
\hline & & & & & $>2,0$ & $\begin{array}{c}0.06- \\
2.00\end{array}$ & $\leq 0.002$ \\
\hline 1 & P1 & 2.527 & 1.693 & 30 & 1,97 & 98,03 & 0,00 \\
\hline 2 & P. 2 & 2.592 & 1.569 & 30 & 2,14 & 97,86 & 0,00 \\
\hline 3 & P. 3 & 2.626 & 1.496 & 30 & 4,30 & 95,70 & 0.00 \\
\hline 4 & P.4 & 2.425 & 1.542 & 30 & 3,13 & 96,85 & 0.02 \\
\hline 5 & P5 & 2.624 & 1.870 & 30 & 2,22 & 97,78 & 13.00 \\
\hline
\end{tabular}

\subsection{Pengolahan Data Dasar Sungai dengan Arcgis}

Pengolahan data yang dilakukan pada penelitian ini untuk menghasilkan informasi profil kedalaman dan permukaan dasar sungai dengan menggunakan echosounder serta mengidentifikasi dan mengukur lapisan lapisan sedimen yang ada di bawah permukaan dasar

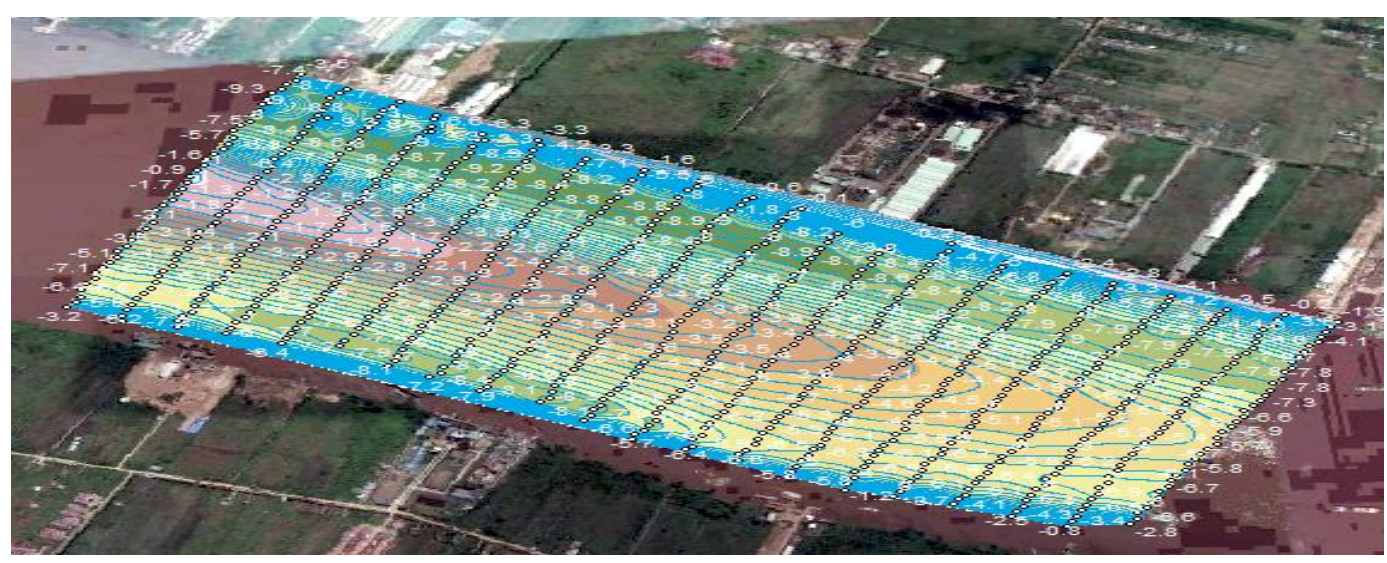

Gambar 3 Peta dan Kontur Bathimatri Dasar Sungai Segmen 1-21

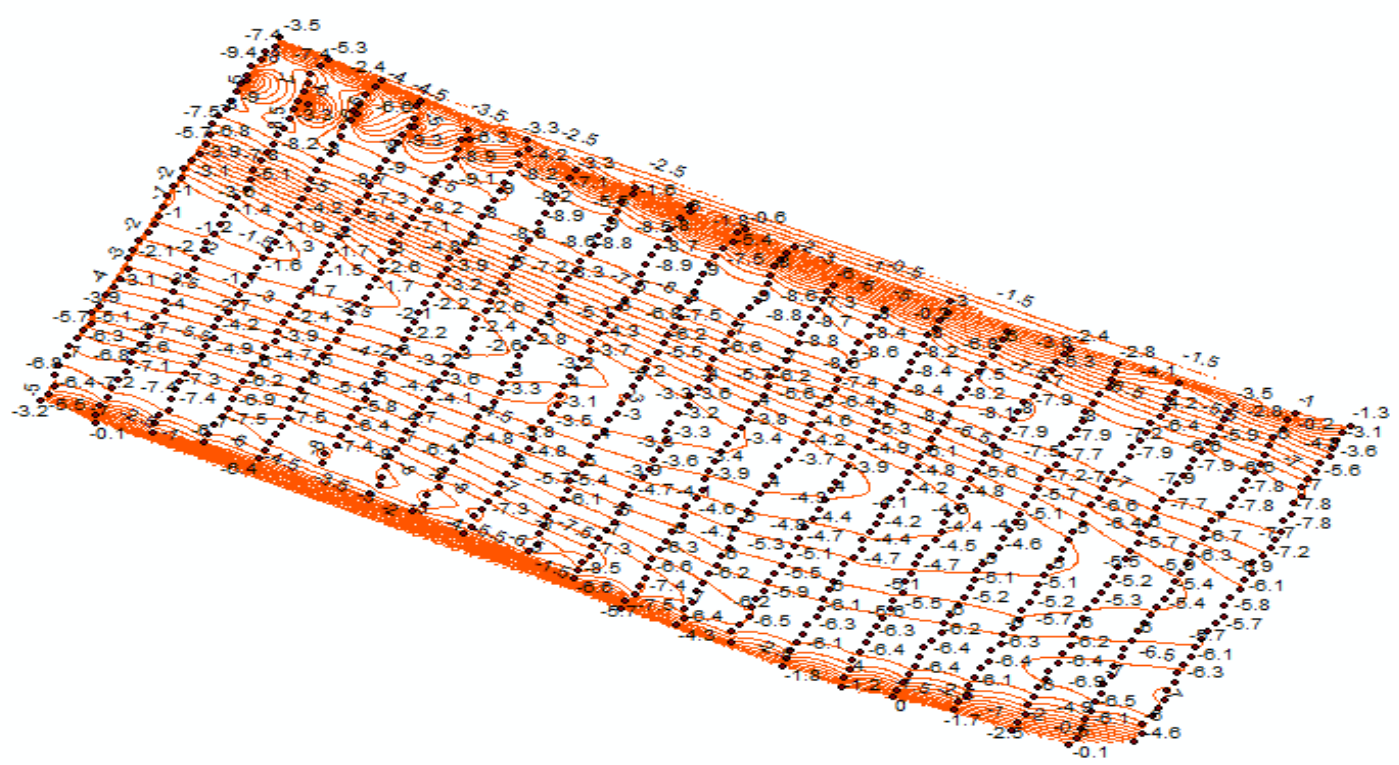

Gambar 4 Kontur Bathimatri Dasar Sungai Segmen 1-21 


\subsection{Dimensi Bentuk Dasar di Sungai Kapuas Kecil Kota Pontianak}

Beberapa peneliti pada bentuk konfigurasi dasar saluran dan perlawanan aliran dalam penelitian ini digunakan metode Van Rijn (1984).

Tabel 2 Perhitungan Tinggi Kedalaman Bentuk Dasar Relatif Penampang 1

\begin{tabular}{rcccccccrrc}
\hline No & $\mathbf{h}$ & $\mathbf{d 5 0}$ & $\mathbf{d 5 0 / h}$ & $\mathbf{S}$ & $\mathbf{V}$ & $\boldsymbol{\Delta} \mathbf{h} \mathbf{1}$ & $\boldsymbol{\Delta} \mathbf{h} \mathbf{2}$ & $\boldsymbol{\Delta \mathbf { 1 }} \mathbf{( c m )}$ & $\boldsymbol{\Delta \mathbf { 2 }} \mathbf{( \mathbf { c m } )}$ & $\mathbf{F r}$ \\
\hline $\mathbf{1}$ & 2.80 & 0.302 & 0.009278 & 0.00073 & 1.564 & 0.027 & 0.025 & 7.55 & 6.88 & 0.298 \\
$\mathbf{2}$ & 4.60 & 0.302 & 0.015243 & 0.00073 & 0.983 & 0.031 & 0.029 & 14.40 & 13.12 & 0.146 \\
$\mathbf{3}$ & 6.00 & 0.302 & 0.019882 & 0.00073 & 0.648 & 0.034 & 0.031 & 20.34 & 18.54 & 0.084 \\
$\mathbf{4}$ & 6.60 & 0.302 & 0.021871 & 0.00073 & 2.438 & 0.035 & 0.032 & 23.02 & 20.98 & 0.303 \\
$\mathbf{5}$ & 6.90 & 0.302 & 0.022865 & 0.00073 & 1.415 & 0.035 & 0.032 & 24.39 & 22.23 & 0.172 \\
$\mathbf{6}$ & 7.20 & 0.302 & 0.023859 & 0.00073 & 1.204 & 0.036 & 0.033 & 25.78 & 23.49 & 0.143 \\
$\mathbf{7}$ & 7.10 & 0.302 & 0.023528 & 0.00073 & 1.368 & 0.036 & 0.032 & 25.31 & 23.07 & 0.164 \\
\hline
\end{tabular}

Tabel 3 Perhitungan Tinggi Kedalaman Bentuk (lanjutan)

\begin{tabular}{|c|c|c|c|c|c|c|c|c|c|c|}
\hline No & h & d50 & 50/h & $\mathbf{S}$ & V & $\Delta / \mathrm{h} 1$ & $\Delta / \mathrm{h} 2$ & $\begin{array}{c}\Delta 1 \\
(\mathbf{c m})\end{array}$ & $\begin{array}{c}\Delta 2 \\
(\mathbf{c m})\end{array}$ & $\mathbf{F r}$ \\
\hline 8 & 6.80 & 302 & 22533 & 00073 & 0.658 & 035 & 32 & 23.93 & 21.81 & 0.081 \\
\hline 9 & 6.70 & 0.302 & 0.022202 & 00073 & 0.170 & 0.035 & 0.032 & 23.47 & 21.39 & 0.021 \\
\hline 10 & 6.30 & 0.302 & 0.020877 & 0.00073 & 0.154 & 0.034 & 0.031 & 21.67 & 19.75 & 0.020 \\
\hline 11 & 6.20 & 0.302 & 0.020545 & 0.00073 & 0.736 & 0.034 & 0.031 & 21.22 & 19.34 & 0.094 \\
\hline 12 & 6.10 & 0.302 & 0.020214 & 0.00073 & 1.893 & 0.034 & 0.031 & 20.78 & 18.94 & 0.245 \\
\hline 13 & 5.80 & 0.302 & 0.01922 & 0.00073 & 1.811 & 0.034 & 0.031 & 19.46 & 17.74 & 0.240 \\
\hline 14 & 5.80 & 0.302 & 0.01922 & 0.00073 & 1.302 & 0.034 & 0.031 & 19.46 & 17.74 & 0.173 \\
\hline 15 & 5.70 & 0.302 & 0.018888 & 0.00073 & 1.420 & 0.033 & 0.030 & 19.03 & 17.34 & 0.190 \\
\hline 16 & 5.70 & 0.302 & 0.018888 & 0.00073 & 0.489 & 0.033 & 0.030 & 19.03 & 17.34 & 0.065 \\
\hline 17 & 5.70 & 0.302 & 0.018888 & 0.00073 & 0.633 & 0.033 & 0.030 & 19.03 & 17.34 & 0.085 \\
\hline 18 & 5.80 & 0.302 & 0.01922 & 0.00073 & 0.432 & 0.034 & 0.031 & 19.46 & 17.74 & 0.057 \\
\hline 19 & 5.90 & 0.302 & 0.019551 & 0.00073 & 1.121 & 0.034 & 0.031 & 19.90 & 18.13 & 0.147 \\
\hline 20 & 6.10 & 0.302 & 0.020214 & 0.00073 & 1.034 & 0.034 & 0.031 & 20.78 & 18.94 & 0.134 \\
\hline 21 & 6.30 & 0.302 & 0.020877 & 0.00073 & 1.137 & 0.034 & 0.031 & 21.67 & 19.75 & 0.145 \\
\hline 22 & 6.60 & 0.302 & 0.021871 & 0.00073 & 0.957 & 0.035 & 0.032 & 23.02 & 20.98 & 0.119 \\
\hline 23 & 6.90 & 0.302 & 0.022865 & 0.00073 & 0.643 & 0.035 & 0.032 & 24.39 & 22.23 & 0.078 \\
\hline 24 & 7.20 & 0.302 & 0.023859 & 0.00073 & 0.669 & 0.036 & 0.033 & 25.78 & 23.49 & 0.080 \\
\hline 25 & 7.30 & 0.302 & 0.02419 & 0.00073 & 1.013 & 0.036 & 0.033 & 26.24 & 23.92 & 0.120 \\
\hline 26 & 7.60 & 0.302 & 0.025184 & 0.00073 & 1.142 & 0.036 & 0.033 & 27.65 & 25.20 & 0.132 \\
\hline 27 & 7.70 & 0.302 & 0.025516 & 0.00073 & 0.273 & 0.037 & 0.033 & 28.13 & 25.64 & 0.031 \\
\hline 28 & 7.80 & 0.302 & 0.025847 & 0.00073 & 0.288 & 0.037 & 0.033 & 28.60 & 26.07 & 0.033 \\
\hline 29 & 7.80 & 0.302 & 0.025847 & 0.00073 & 2.269 & 0.037 & 0.033 & 28.60 & 26.07 & 0.259 \\
\hline 30 & 7.00 & 0.302 & 0.023196 & 0.00073 & 2.068 & 0.035 & 0.032 & 24.85 & 22.65 & 0.250 \\
\hline 31 & 7.50 & 0.302 & 0.024853 & 0.00073 & 2.922 & 0.036 & 0.033 & 27.18 & 24.77 & 0.341 \\
\hline 32 & 6.70 & 0.302 & 0.022202 & 0.00073 & 2.747 & 0.035 & 0.032 & 23.47 & 21.39 & 0.339 \\
\hline 33 & 6.20 & 0.302 & 0.020545 & 0.00073 & 0.803 & 0.034 & 0.031 & 21.22 & 19.34 & 0.103 \\
\hline 34 & 5.60 & 0.302 & 0.018557 & 0.00073 & 0.869 & 0.033 & 0.030 & 18.59 & 16.95 & 0.117 \\
\hline
\end{tabular}






Geometri bentuk konfigurasi dasar disebabkan oleh terakumulasinya ukuran kekasaran dasar ekivalen. Dalam ungkapan yang paling sederhana, kekasaran bentuk $\left(k_{s}{ }^{\prime \prime}\right)$ setara dengan ketinggian bentuk konfigurasi dasar $(\Delta)$, yakni $\mathrm{k}_{\mathrm{s}}{ }^{\prime \prime} \approx \Delta$

\subsection{Prediksi Perlawanan Dasar di Sungai Kapuas Kecil Kota Pontianak}

Perlawanan pada dasar yang terdapat bentuk dasar, meliputi dua komponen yakni perlawanan gesekan butiran dan perlawanan bentuk yang diamati oleh Talebbeydokhti et al. (2006)

Tabel 4 Resume Nilai Kekasaran Mannning Metode Talebbeydokhti et al. (2006)

\begin{tabular}{|c|c|c|c|c|c|c|c|c|c|}
\hline Segmen & $\begin{array}{c}\mathrm{d50} \\
(\mathrm{mm})\end{array}$ & $\Delta / \mathrm{h} 1$ & $\Delta / \mathrm{h} 2$ & $\Delta 1(\mathrm{~cm})$ & $\Delta 2(\mathrm{~cm})$ & $\mathrm{Fr}$ & n" & $n^{\prime}$ & $n$ \\
\hline 1 & 0.250 & 0.034 & 0.031 & 20.689 & 18.856 & 0.177 & 0.0034 & 0.0119 & 0.0153 \\
\hline 2 & 0.250 & 0.033 & 0.032 & 20.167 & 19.557 & 0.188 & 0.0035 & 0.0119 & 0.0153 \\
\hline 3 & 0.250 & 0.034 & 0.034 & 20.781 & 20.781 & 0.168 & 0.0035 & 0.0119 & 0.0154 \\
\hline 4 & 0.250 & 0.021 & 0.034 & 12.276 & 19.929 & 0.173 & 0.0035 & 0.0119 & 0.0154 \\
\hline 5 & 0.250 & 0.033 & 0.033 & 19.355 & 19.537 & 0.210 & 0.0035 & 0.0119 & 0.0154 \\
\hline 6 & 0.250 & 0.035 & 0.035 & 20.962 & 20.961 & 0.210 & 0.0036 & 0.0119 & 0.0154 \\
\hline 7 & 0.250 & 0.035 & 0.035 & 20.849 & 20.849 & 0.209 & 0.0036 & 0.0119 & 0.0154 \\
\hline 8 & 0.250 & 0.035 & 0.035 & 20.476 & 20.475 & 0.220 & 0.0035 & 0.0119 & 0.0154 \\
\hline 9 & 0.250 & 0.035 & 0.035 & 21.231 & 21.231 & 0.206 & 0.0036 & 0.0119 & 0.0154 \\
\hline 10 & 0.250 & 0.035 & 0.035 & 21.672 & 21.672 & 0.210 & 0.0036 & 0.0119 & 0.0154 \\
\hline 11 & 0.250 & 0.035 & 0.035 & 20.807 & 20.806 & 0.232 & 0.0035 & 0.0119 & 0.0154 \\
\hline 12 & 0.250 & 0.034 & 0.034 & 20.207 & 20.206 & 0.243 & 0.0035 & 0.0119 & 0.0154 \\
\hline 13 & 0.250 & 0.034 & 0.034 & 20.328 & 20.327 & 0.262 & 0.0035 & 0.0119 & 0.0154 \\
\hline 14 & 0.250 & 0.035 & 0.035 & 20.745 & 20.744 & 0.227 & 0.0035 & 0.0119 & 0.0154 \\
\hline 15 & 0.250 & 0.035 & 0.035 & 20.443 & 20.442 & 0.219 & 0.0035 & 0.0119 & 0.0154 \\
\hline 16 & 0.250 & 0.034 & 0.034 & 19.988 & 19.988 & 0.192 & 0.0035 & 0.0119 & 0.0154 \\
\hline 17 & 0.250 & 0.034 & 0.034 & 20.377 & 20.377 & 0.192 & 0.0035 & 0.0119 & 0.0154 \\
\hline 18 & 0.250 & 0.034 & 0.034 & 19.529 & 19.529 & 0.195 & 0.0035 & 0.0119 & 0.0154 \\
\hline 19 & 0.250 & 0.033 & 0.033 & 18.976 & 18.976 & 0.198 & 0.0035 & 0.0119 & 0.0154 \\
\hline 20 & 0.250 & 0.033 & 0.033 & 17.510 & 17.510 & 0.205 & 0.0035 & 0.0119 & 0.0153 \\
\hline 21 & 0.250 & 0.032 & 0.032 & 17.389 & 17.389 & 0.208 & 0.0035 & 0.0119 & 0.0153 \\
\hline
\end{tabular}

Berdasarkan hasil perlawanan diperoleh berkisar antara 0,0153 sampai 0,057 


\subsection{Penentuan Bentuk Dasar di Sungai Kapuas Kecil Kota Pontianak Berdasarkan Grafis}

Bentuk konfigurasi dasar akan terbentuk menjadi beberapa tipe topografi vertikal mulai dari fraksi milimeter sampai beberapa meter. Penelitian yang dilakukan di Sungai Kapuas Kecil Kota Pontianak, menemukan bahwa bentuk umum dari beberapa geometri dasar, berkembang di bawah arus searah dan keseluruhan geometri tergantung pada kondisi aliran dan sifat sedimen. Keseluruhan geometri dasar disebut sebagai konfigurasi bentuk dasar, yang terdiri dari banyak elemen topografi individu.

Analisis penentuan jenis bentuk konfigurasi dasar dilakukan berdasarkan grafik dan rumusan empiris pada penelitian sebelumnya. Metode grafis dilakukan dengan menggunakan metode (Simons and Richardson, 1966) dan (Van Rijn, 1993)

Menunjukan hasil bentuk dasar dunes dan plane, antidunes. Selain itu pula terjadi pada regime rendah.
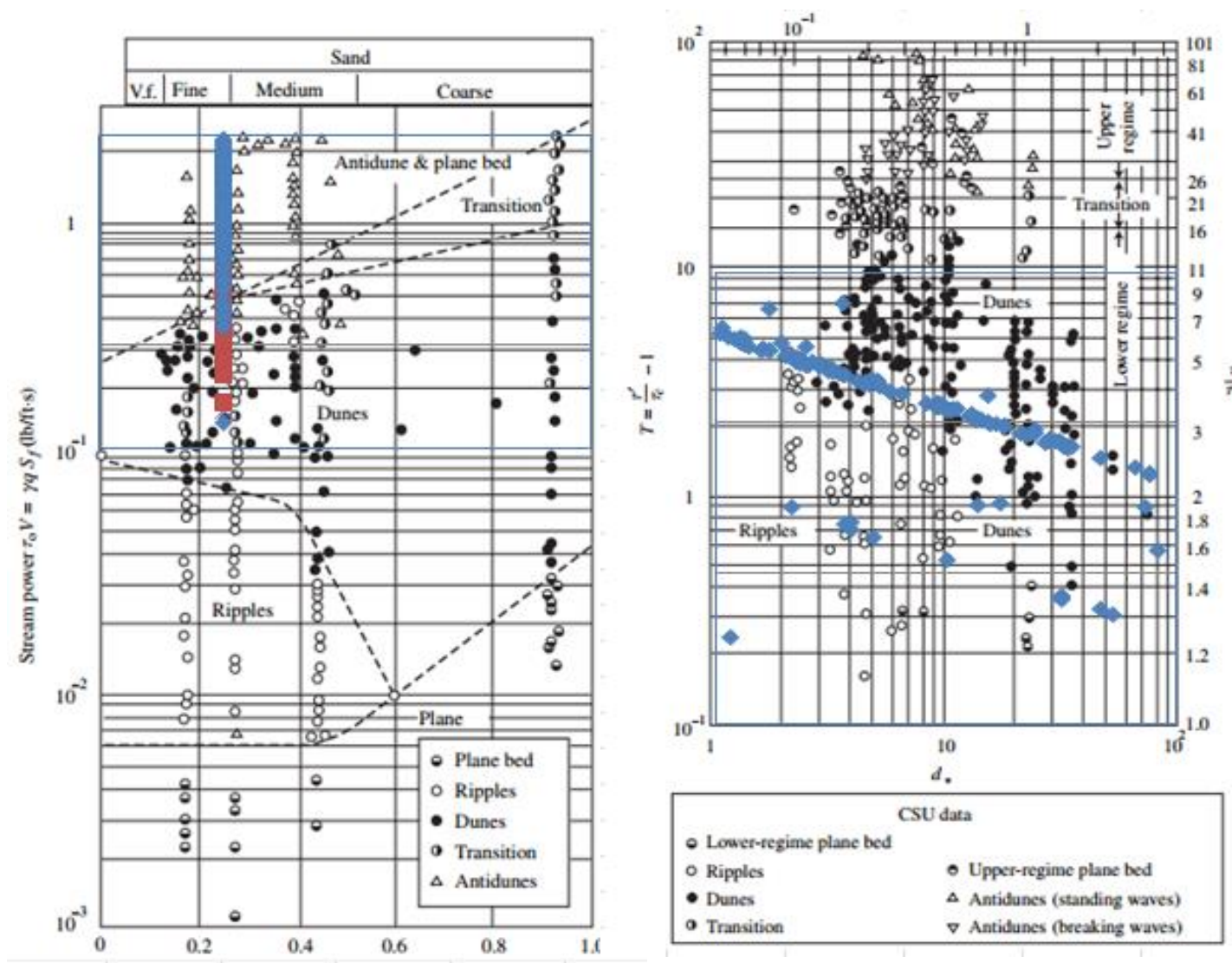

Gambar 5 Bentuk dasar Berdasarkan Metode Simon and Richardson (1966) dan Van Rijn (1993)

\section{Kesimpulan dan Saran}

\subsection{Kesimpulan}

Penelitian ini mengkaji perlawanan dasar yang terjadi di Sungai Kapuas Kecil Kota Pontianak. Bentuk perlawanan dasar saluran dinyatakan dengan koefisien kekasaran dasar Manning pada material non kohesif di saluran aluvial. Kegiatan yang dilakukan yakni penelitian lapangan dengan menggunakan 
rumusan yang melibatkan bentuk konfigurasi dasar. Hasil penelitian menyimpulkan sebagai berikut

1. Hasil penelitian pada bentuk dasar yang terjadi berupa dunes plane bed dan antidunes dengan tinggi gelombang pasir skala antara $(11,904-37,044 \mathrm{~cm})$, terjadi di regime aliran rendah dan memiliki bilangan Froude pada ukuran butiran $(0,338-0,850)$ kurang dari 1 .

2. Geometri bentuk konfigurasi dasar pada Lokasi Penelitian di Sungai Kapuas Kecil di Pontianak berupa tinggi dasar $(\mathrm{ks} " \approx \Delta)$. Nilainya sebesar 11,904$37,044 \mathrm{~cm}$.

3. Nilai perlawanan dasar dalam bentuk nilai koefisien kekasaran Manning, yang diakibatkan komponen kekasaran butiran dan perlawanan bentuk berkisar antara 0,0153 sampai 0,057

\subsection{Saran}

Berdasarkan penelitian ini dapat diberikan saran-saran sebagai bentuk rekomendasi sebagai berikut:

1. Perlu kontrol nilai kekasaran dengan metode lainnya (bajorunas)

2. Pengambilan data arus dan tanah sebainya pada satu segmen yang sama

3. Pemodelan lebih mendalam pada bentuk transisi dunes, plane bed dan antidunes

\section{Ucapan Terima Kasih}

Ucapan terima kasih pada Fakultas Teknik yang telah memberikan dana untuk pembiayaan kegiatan penelitsn ini.

\section{Daftar Kepustakaan}

Bajorunas, L., Banks, R., Blench, T., Chow, V., Doland, J., Inglis, C., 1952. Discussion of" River Channel Roughness. Trans. Am. Soc. Civ. Eng.

Chow, V.T., 1959. Open-Channel Hydraulics. NY etc.

Einstein, H.A., 1952. River Channel Roughness. Trans. ASCE 117, 1121-1132.

Engelund, F., Hansen, E., 1967. A Monograph On Sediment Transport In Alluvial Streams. Tech. Univ. Den. 0stervoldgade $10 \mathrm{Cph}$. K.

Kazemipour, A., Apelt, C., 1983. Effects of Irregularity of Form on Energy Losses in Open Channel Flow.

Knighton, A.D., 1999. Downstream Variation in Stream Power. Geomorphology 29, 293-306.

Kodoatie, R., 2009. Hidrolika Terapan,Aliran pada Saluran Terbuka dan Pipa". Edisi Revisi Cetakan ke IV. CV Andi Offset Yogyak.

Simons, D.B., Richardson, E.V., 1966. Resistance to Flow in Alluvial Channels. US Government Printing Office.

Simons, D.B., Şentürk, F., 1992. Sediment Transport Technology: Water And Sediment Dynamics. Water Resources Publication. 
Strickler, A., 1923. Contributions To The Question Of The Rate Formula And The Roughness Numbers For Flows, Channels And Closed Lines. Im Selbstverlag.

Talebbeydokhti, N., Hekmatzadeh, A., Rakhshandehroo, G., 2006a. Experimental Modeling Of Dune Bed Form In A Sand-Bed Channel. Iran J Sci Technol Shiraz Univ Trans B Eng 30.

Talebbeydokhti, N., Hekmatzadeh, A.A., Rakhshandehroo, G.R., $2006 \mathrm{~b}$. Experimental Modeling of Dune Bedform in A Sand Bed Channels. Iran. J. Sci. Technol. 30, 503-516.

Toyama, A., Shimizu, Y., Yamaguchi, S., Giri, S., 2007. Study Of Sediment Transport Rate Over Dune-Covered Beds. Presented at the 5th IAHR symposium on river, coastal and estuarine morphodynamics. University of Twente, Enschede.

Van der Mark, C., 2009. A Semi-Analytical Model For Form Drag Of River Bedforms. Univ. Twente Neth.

van Duin, O.J., Ribberink, J.S., Dohmen-Janssen, C.M., Hulscher, S.J., 2013. Modelling Sediment Pick-up and Deposition in a Dune Model. VLIZ Spec. Publ.

Van Rijn, L.C., 1993. Principles Of Sediment Transport In Rivers, Estuaries And Coastal Seas. Aqua publications Amsterdam.

Wibowo, H., 2017. Aplikasi Debit Aliran Menggunakan Koefisien Dasar Dengan Didasarkan Bentuk Konfigurasi Dasar Saluran. J. Tek. Sipil 18.

Wibowo, H., 2015. Manning Roughness Coefficient Study on Bed Materials NonCohesive with Parameters Using Entropy to Open Channel Flow. Presented at the International Conference on Coastal and Delta Areas, pp. 238-253.

Yalin, M., 1992. River Mechanics, 219 pp. 